\title{
On the way to the best possible science: An intellectual travel guide
}

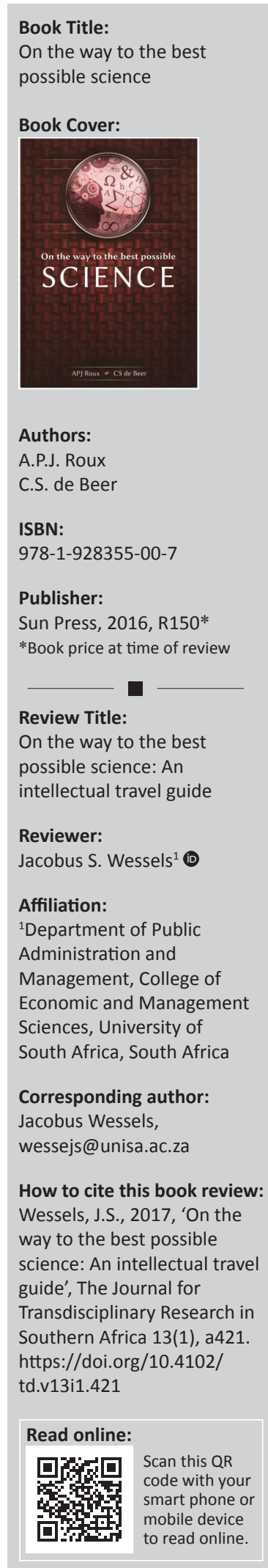

It is not easy to ignore a book with a title such as On the Way to the Best Possible SCIENCE, when it waits for you right in the middle of your pathway - except if you are perhaps not into travelling at all. However, most of us who work in the world of science are currently completing application forms to obtain funding for endeavours on the way to some or other best possible scholarly destination. Our ultimate destination may vary from the well-intended exploration of new ideas that may 'truly benefit humanity' (Roux \& De Beer 2016:129) to the refining of practices to maximise some unintended benefit for ourselves. As I constantly find myself on the way to promising destinations, I could not ignore a book with the potential not only to change my perspective on my best possible destination but also to change my destiny. This book is On the Way to the Best Possible SCIENCE by A.P.J Roux and C.S. De Beer. The late Braam Roux was Emeritus Professor of Philosophy at the University of South Africa until he passed away in September 2012. Fanie de Beer, Emeritus Professor in the Department of Information Science, University of South Africa, is currently associated with the Department of Information Science, University of Pretoria. The book was first published in 2014 under the title Onderweg na die Beste Moontlike WETENSKAP. The English translation was done by Irma Kroeze, Department of Jurisprudence, University of South Africa.

As a scholar of a subject field with a special interest in attaining the best possible life for all the citizens of a country, I did not dare pass this book by, as the sounds of familiar concepts such as 'measure', 'function', 'strategy', 'vision', 'policy', 'precondition', 'evaluation' and 'communication' beckoned me to investigate further. These concepts are used in public administration to explore, explain, describe and reflect on the way to the best possible life for all citizens.

Used to reading travel guides, I opened the book at what seemed to be the most appropriate place for directions to the best possible destination, namely Chapter 2, with the title 'The function of strategy, vision and policy'. And, I wondered why the authors decided not to call this chapter 'In the way to the best possible science'.

This book by Roux and De Beer has become my travel guide for exploring policies, visions, strategies and operational plans as possible prerequisites for or obstacles to the occurrence of science, and more specifically, the best possible science within the context of South African higher education. For two scholars to journey in more or less the same direction requires a shared understanding of 'science', in this case within the South African context, as well as its preconditions and consequences.

The title of this book, On the way to the best possible SCIENCE, poses a challenge to the reader's own understanding of the concept 'science', even before they can determine how Roux and De Beer understood 'science' when they coined the title of their book. Considering the diverse uses of the concept, one may rightfully doubt whether agreement on the use of the concept 'science' is possible. John Wilson (1985:54) in his work Thinking with concepts (first published in 1963) warns that there is no 'such thing as "the" meaning of a word' or " "the" concept of a thing'. He proceeds by explaining, 'we can talk about your concept, ... or my concept, or Cicero's concept' (Wilson 1985:54). The defining elements or attributes of Roux and De Beer's concept of 'science' gradually unfold when reading this book.

The most striking defining attribute of their use of 'science' is encapsulated in the following sentence, 'The basis of science is a human being who wants to understand and know his [or her] world' (p. 60) [author's emphasis]. Without the presence of the human being, the word 'science' will apparently mean something different. The human being (pp. 60, 63), constituting the core

Copyright: (c) 2017. The Authors. Licensee: AOSIS. This work is licensed under the Creative Commons Attribution License. 
element of the authors' concept 'science', serves as qualifier for all the other elements of their use of 'science', such as critical tradition (pp. 59, 63, 86, 87, 99, 115), knowledge (pp. 18, $59,60,69,82,86,115$ ), enquiry (pp. 59, 82), systematise (pp. 59, 63,86 ), share and discourse (pp. 59, 69, 74, 79) and tentative (p. 59). These elements are eventually human in nature.

For Roux and De Beer, the best possible science relates primarily to the human being with 'a particular human interest in and relationship with society' (p. 63). The element critical tradition can also be traced back to the scholar and the conditioned habits and conventions of their diverse societies (pp. 59, 63, 86, 87, 99, 115). It is especially the knowledge and knowing element (pp. 18, 59, 60, 69, 82, 86, 115) of science that relates directly to society. The nature and trustworthiness of knowledge are expected to respond to the needs and expectations of society - therefore, the specific traditions of enquiry, systematising, openness, sharing and tentativeness that characterise science.

Is it possible for science to exist on its own? If not, what needs to be in place for the concept 'science' to exist? Walker and Avant (2014) refer in this regard to the antecedents of a concept as 'those events or incidents that must occur or be in place prior to the occurrence of a concept' (Walker \& Avant 2014:173). Roux and De Beer (2016) Identify several antecedents for 'science' within the South African higher education context. These antecedents are mostly of an extrascientific nature and include 'preferences, prejudices and assumptions, ideologies, paradigms, convictions and faith' (p. 82). The nature of these antecedents implies that the aptitude for research, the motivation for certain research and projects' (p. 82) has its origin and meaning outside the realm of science. The above-mentioned incidents of extrascientific human orientations can only be expressed through language. For Roux and De Beer, science 'is impossible without language' (p. 83). Closely related to this antecedent is the social context of science 'in which requirements, interests and views of society and of government is present' (p. 30). This context implies a 'social embeddedness ... and ... the community's involvement in science' (p. 85) as well as adherence to ethical guidelines 'based on the existing norms in a community' (p. 85). Through their respect for these norms, scientists may earn the trust of society - a prerequisite for meaningful science (p. 79). Roux and De Beer also attend to the more formal antecedents for science, namely prerequisites such as 'comprehensive institutional involvement and large financial inputs' (p. 99).
These prerequisites are directed by the visions, strategies and policies as published by the relevant institutions (p. 37). The institutionalised nature of especially the latter antecedents may unevenly influence the defining attributes of science, which subsequently influence the consequences of science. The authors have eloquently demonstrated that science does not exist in a clinical vacuum. Science is influenced and it influences for the better or the worse.

This brings us to the consequences of science: are they good or are they bad? With the human being as a central defining attribute of science, and language as a prerequisite for science (p. 83), a key consequence of science is 'meaning', as determined by the 'values and ideals that humans have' (p. 108). Not only do Roux and De Beer argue for socially embedded science relevant to the 'requirements, interests and views of society and of government' (p. 30), but they express their frustration with the seemingly neglect of the 'dimension of real distress or need' (p. 92) by the official strategies, visions and policies. Roux and De Beer argues for a science, which:

- respects and accepts the uniqueness and values of individuals constituting society (p. 58)

- realises human ideals and motives (p. 108)

- fosters peace and prosperity, as opposed to 'distress and need' (p. 92)

- stimulates trustworthy intellectual social engagement with conversation partners (p. 79)

- contributes to credible knowledge (p. 85).

On the way to the best possible SCIENCE was published by SUN MeDIA MeTRO under the SUN PRESS imprint. It consists of four chapters, namely 'Peer review: reliable measuring scale or superfluous practice?', 'The function of strategy, vision and policy', 'Preconditions for the best possible science' and 'Evaluation and communication'. This book cannot be ignored by any serious explorer of the world of science. It serves as a caring intellectual guide on the way to the best possible science, whatever meaning this may have for the individual traveller.

\section{References}

Roux, A.P.J. \& De Beer, C.S., 2014, Onderweg na die beste moontlike wetenskap, Sun Press, Stellenbosch.

Roux, A.P.J. \& De Beer, C.S., 2016, On the way to the best possible science, Sun Press, Stellenbosch.

Walker, L.O. \& Avant, K.C., 2014, Strategies for theory construction in nursing, 5th edn., Pearson new international edition, Pearson, New York.

Wilson, J., 1985, Thinking with concepts, Cambridge University Press, Cambridge. 